\title{
症例
}

\section{子宮頸部悪性腺腫の 2 例}

\author{
成田赤十字病院病理検查課 ${ }^{12}$, 同 婦人科 ${ }^{2}$, 同 病理部 ${ }^{3)}$ \\ 千葉大学教育学部保健教育 ${ }^{4)}$, 埼玉医科大学総合医療センター病理部 ${ }^{5)}$ \\ 中原 裕子1) 柏尾 純子1) 斉藤 忠 ${ }^{11}$ 石井 譲 ${ }^{21}$ \\ 外丸 和弘 ${ }^{2)}$ 田丸 淳一5) 武田 敏 ${ }^{4)}$ 三方 淳男 ${ }^{3)}$
}

\begin{abstract}
背景：子宮頸部擦過細胞診で悪性腺腫（Adenoma malignum）が示唆された 2 症例を経験した ので報告する。

症例：症例 1 は 48 歳, 症例 2 は 41 歳, ともに経産婦で帯下の異常を主訴に来院した. 症例 1 , 2 ともに靧部は腫大し, 画像診断で腫瘤病変並びに多囊胞形成がみられた。両者ともCA 125 の上 昇を認めたがその他検査值には異常を認めなかった。 子宮頸部擦過細胞診では多量の粘液を背景 に, 細胞質内に黄〜黄緑色の異常粘液を含む異型細胞の出現をみた。核は基底部に位置しクロマチ ンは細顆粒状融解状で, 核内にはときに著明な核小体を認めた。粘液による核の圧排像も観察され た。臨床からの詳細な情報の提供とこれら細胞診所見より悪性腺腫が示唆され, 円錐切除組織診に て診断が得られ, 摘出手術が施行された. 粘液染色では症例 1,2 ともPAS 染色は強陽性なのに 対し, ALB や HID-ALB 染色では染色性の低下がみられた. HIK 1083 は症例 1,2 ともに陽性を 示していた。
\end{abstract}

結論：細胞異型に乏しいとされる悪性腺腫は, 臨床所見や特殊染色の結果を考慮することで診断 が可能と思われた。

Key words : Uterine cervix —-Adenoma malignum-Cytochemistry-Endocervical scraping cytology—Case report

Two cases of adenoma malignum of the uterine cervix Hiroko NAKAHARA ${ }^{1)}$, C.T., I.A.C., Junko KAYAO ${ }^{1)}$, C.T., C.M.I.A.C., Tadashi SAITO' ${ }^{1)}$, C.T., I.A.C., Jo ISHII ${ }^{2)}$, M.D., Kazuhiro TOMARU ${ }^{2)}$, M.D., Jun-ichi TAMARU ${ }^{5)}$, M.D., Bin TAKEDA $^{4)}$, M.D., Atsuo MIKATA ${ }^{3)}$, M.D.

${ }^{1)}$ Department of Pathology, ${ }^{2}$ Department of Obstetrics and Gynecology, ${ }^{3}$ Department of Pathology, Narita Red Cross Hospital

${ }^{4}$ Department of Health Education, Chiba University School of Education

${ }^{5)}$ Department of Pathology, Saitama Medical Center, Saitama Medical School

論文別刷請求先 $\bar{\top} 286-8523$ 成田市飯田町 90 の 1 成田赤 十字病院病理検查課 中原裕子.

平成 11 年 12 月 9 日受付

平成 12 年 11 月 2 日受理

\section{I. はじめに}

内頸部型粘液性腺癌に属する悪性腺腫 (Adenoma malignum, 以下 AM) は, 1870 年 Gusserow が初め て報告した病変で1), 子宮頸部腺癌の $1.54 \%$ にみら れる比較的まれな腫瘍である ${ }^{21}$.また細胞異型に乏し く, 細胞学的にも組織学的にも正常の頸管腺上皮に類 似するために診断に苦慮することが多く，早期からリ ンパ節転移を来たすことからも予後不良とされてい る. 今回われわれは子宮頸部擦過細胞診にて示唆さ れ, 早期に術前診断の出来た AM の 2 症例について 検討したので報告する。 


\section{II. 症例}

\section{1. 症例 1}

患 者：48 歳, 主婦, 4 妊 3 産

主 訴：白色粘液性带下

家族歴/既往歴：特記すべきことなし

現病歴：96 年 8 月頃より白色粘液性帯下を認め, 97 年 8 月他院にて子宮頸部腫瘍が疑われ, 同年 12 月 当院婦人科を受診した。初診時所見では子宮頸部は鵎 卵大に腫大しており，画像診断にて多囊胞形成（最大 $1.5 \mathrm{~cm} ）$ が認められた。入院時検査では CA 125 が高 值 $(60.6 \mathrm{U} / \mathrm{m} l$, 正常值 $35 \mathrm{U} / \mathrm{m} l$ 以下) を示したも のの他の数値は正常範囲内であった。 子宮頸部擦過細 胞誩扔よび子宮頸部円錐切除術により $\mathrm{AM}$ と診断さ れ広沉性子宮全摘術が施行された。子宮摘出材料に抒 いて子宮前壁が腫大しており，同部の割面は白色調で 表面は粘稠性だった。多数の囊胞化した腺管もみられ た (Photo. 1). 臨床進行期はII a 期で, 術後 35 力月 を経過した現在（2000 年 11 月現在）も再発は認めら れていない.

\section{2. 症例 2}

患 者：41 歳, 主婦, 2 妊 1 産

主 訴: 水様性帯下の増加

家族歴：特記すべきことなし

既往歴：慢性甲状腺炎（87 年～)

現病歴：98 年 5 月頃より帯下増加にて近医を受診 したところ子宮頸部腫場が疑われ，同年 6 月当院婦人 科を受診した。入院時検査では CA 125 が高値（53.1 $\mathrm{U} / \mathrm{m} l)$ を示したものの他の数值は正常範囲内であっ た。宮頸部擦過細胞診抢よび生検材料にて悪性病 変，腺癌を強く疑い，同年 8 月広沉性子宮全摘術なら びに骨盤内リンパ節郭清が施行された．子宮摘出材料 では子宮頸部後壁に腫大がみられ，割面は粘稠性であ つた（Photo. 2)。また本症例においては，リンパ節 転移もみられた。臨床進行期はII a 期で術後 27 カ月 を経過した現在（2000 年 11 月現在）も再発は認めら れていない.

\section{III. 細 胞 所見}

\section{1. 症例 1}

子宮頸部擦過細胞診では多量の粘液を背景に腫瘍細 胞は大型のシート状, 蜂巣状集塊として出現してい
た。また腺房状，リボン状や腺腔様配列，一部に核が 外方へ突出する花弁状配列もみられた，高円柱状腫瘍 細胞の細胞質内には黄〜黄緑色の粘液がみられ, 腫場 細胞の産生する異常粘液により核が圧排される様子も 観察された．核は円〜類円形が主体で，中には長楕円 形核もみられた。核は大小不同性に乏しく，クロマチ ンは細顆粒状で融解状を示し，核縁の肥厚がみられ た。核小体は 1 数個みられ，大型の核小体が目立っ た (Photo. 3)。一部には異型を伴った高分化腺癌に 相当する細胞もみられた。

手術捺印標本でも異型に乏しい腫瘍細胞の大型シー 卜状集塊や，高円柱状細胞の柵状配列がみられ，子宮 頸部擦過細胞診でみられた細胞に類似していた。これ らの細胞には HIK 1083 陽性の粘液を認めた（Photo. 4).

\section{2. 症例 2}

子宮頸部擦過細胞診での腫瘍細胞の特徵は症例 1 の それと同様であり，乳頭状増殖を示す腫瘍細胞の細胞 質には多量の黄色粘液が充満し, 核が強度に圧排され ていた（Photo.5)。個々の細胞に大小不同や核分裂 像もみられた。

手術時捺印標本でも黄緑色の多量の異常粘液により 核が圧排されており (Photo. 5), 粘液産生能の著し い様子が観察された。蜂巣状を呈する集塊の辺縁部で は核密度が上昇するものの，核は基底部に位置してい た。結合性の低下により散在する細胞も出現してい た。これらは子宮頸部擦過細胞診にみられた細胞と同 様と思われた。

\section{IV．病理組織所見}

\section{1. 症例 1}

子宮摘出材料において, 細胞異型に乏しい高円柱上 皮よりなる腺管が不規則な分岐を示しながら筋層深く 浸潤していた。また腔内へ突出するへアピン状発育も みられた。腫湯細胞の核は基底部に位置しており, 細 胞質内には多量の粘液を含み，間質への粘液の遊出も 認めた。一般に深部浸潤腺管ほど細胞異型は強く, 一 部には核異型を伴い明らかに腺癌を疑う細胞もみられ た.

特殊染色を行ったところ, 腫瘍細胞は Periodic Acid Shiff 染色（以下 PAS）に強陽性を示したが， Alcian Blue 染色 (以下 ALB) では明らかに酸性粘 液の染色性が低下して扔り，不均一な染まり方をして 
いた.さらに High Iron Diamin-Alcian Blue 染色 （以下 HID-ALB）では黒紫色に染まるスルホムチン と青色に染まるシアロムチンが混在していた。またグ リメリウス染色では腫瘍腺管内に好銀性顆粒を有する 細胞がみられた。免疫組織化学では HIK 1083 は陽性 を示した (Photo.6).CEA はごく一部の細胞に陽 性, p 53 は陰性であった。

\section{2. 症例 2}

子宮摘出材料において著明な粘液産生性の高円柱上 皮細胞が複雑な乳頭状, 囊胞状の腺腔を形成して深部 に浸潤，増殖していた。リンパ節転移巣の腫崵細胞も ほほ同様の所見で不規則な腺腔形成もみられた。腫瘍 細胞はPASが強陽性を示していたのに対し, ALB, HID-ALB では著明な染色性の低下および不均一な染 まり方がみられた。グリメリウス染色は陰性だった。 免疫組織化学では HIK 1083 陽性, CEA はごく一部 の細胞に陽性を示していた。CA 125 は発現の減弱が みられた。リンパ節転移巣の細胞のみが p 53 陽性で あった.

\section{V. 子宮頸部および胃粘膜の粘液との比較}

\section{1. 材料と方法}

AM に出現する粘液および腫瘍細胞の形態学的特 徵を明らかにするために, 子宮頸管腺および胃粘膜の 粘液との比較検討を試みた。検討に際し選択した材料 は $\mathrm{AM}$ の自験例 2 例, 子宮筋腫切除例の正常頸管腺 3 例, 子宮頸部腺癌 1 例, 早期胃癌切除例に扔ける非 癌部の幽門腺および表面粘液細胞各 2 例である。これ らの材料のホルマリン固定パラフィン包埋切片を用 い, 特殊染色抢よび免疫染色に扔ける各粘液の染色態 度について検討を行った. 免疫染色で使用した抗体は HIK 1083 (関東第一化学), CEA おょびp 53 (DAKO 社) で，手技は ENVISION 法 (DAKO 社) にて行った。なお判定は標本中に出現している対象と なる各細胞の $80 \%$ 以上に陽性所見を認めた場合に $3+$ とし，80〜60\%を $2+, 60 \sim 30 \% を+， 30 \sim 10 \%$ を+/ー, 10\% 以下をーとした.

\section{2. 結果}

正常の頸管腺粘液は PAS, ALB, HID-ALB がほ とんどすべての細胞で強陽性であり, スルホムチンが 主体であることが示唆された. HIK 1083 と CEA は 全く陰性であった。通常の子宮頸部腺癌ではPAS, ALB，HID-ALB は粘液産生細胞の $1 / 3$ 以下で強〜
弱陽性, HIK 1083 は陰性であった. 胃の幽門腺細胞 はPAS, ALB，HID-ALB，HIK 1083 はすべて陽性 であるのに対し, 表面粘液細胞はPAS のみ強陽性を 示していた。AMの 2 症例ではほとんどの細胞で PAS は強陽性を示し, ALB は $1 / 3$ 以上の細胞で陽性 ないし弱陽性で HID-ALB とともに正常頸管腺粘液 に比べて染色性が低下していた。 HIK 1083 は2 症例 ともに陽性であり, 症例 1 では陽性細胞は 60 ～ $80 \%$ に達した. CEA もごく一部の細胞で陽性であった。 上記より $\mathrm{AM}$ の粘液は胃の幽門腺粘液染色態度に近 似する結果であった。以上の結果を Table 2 に示し た.

\section{VI. 考察}

われわれは子宮頸部擦過細胞診にて示唆された AM 2 症例経験した。その細胞所見の中でも特に 粘液の特徴に注目した. 2 症例の細胞形態学的特徴と して, 多量の粘液を背景に腫瘍細胞は大型のシート状 集塊や蜂巣状, 柵状配列で出現していた。個々の細胞 は高円柱状で黄色粘液を有する細胞や, 異常粘液によ り核が圧排される像も観察された。核は円〜類円形で 緊満感があり,クロマチンは微細顆粒状, 核小体は 1 ～2 個, 時に大型のものも認めた (Table 1).これら の細胞所見は芳賀ら ${ }^{2)}$ および荒井ら ${ }^{3)}$ の報告とほぼ 同様であった。通常正常の頸管腺粘液は Papanicolaou 染色においては淡赤〜淡紫色を呈し, PAS，ALB はともに陽性で，さらに酸性粘液の中で もスルホムチンを主体とする粘液である. 今回われわ れが経験した AM は 2 症例とも Papanicalaou染色 で黄色調粘液を認め, PAS は強陽性を示すのに対し, ALBでは明らかに酸性粘液の染色性が低下していた。 加えて, スルホムチンの減少とともにシアロムチンが 証明され，同一腺管でも両者が混在していた。 Toki ら5)もれに類似する所見を述べており, 酸性粘液の 染色性の低下, スルホムチンとシアロムチンの染色性 の逆転も注目すべき所見の1つではないかと思われ た。この異常粘液は胃型粘液であるとする報告があ る ${ }^{4 \sim 8)}$.これらの報告によると, AM では高率に胃上 皮化生様細胞が認められて抢り, 免疫染色に扔いて $\mathrm{AM}$ の粘液は胃幽門腺由来粘液を認識する HIK 1083 抗体に陽性を示す. AM の一部はこの胃上皮化生様 の腺管群より発症している可能性が示唆されている. われわれの症例 1,2 で出現していた粘液もPASで 
Table 1. Cytomorphological features in endocervical columnar cell lesions

\begin{tabular}{|c|c|c|c|}
\hline & $\begin{array}{l}\text { Benign endocervical } \\
\text { glands }\end{array}$ & $\begin{array}{l}\text { Endocervical } \\
\text { adenocarcinoma }\end{array}$ & Adenoma malignum \\
\hline Appearance & $\begin{array}{l}\text { - Sheets } \\
\text { - No stratification }\end{array}$ & $\begin{array}{l}\text { - Irregular configuration } \\
\text { - Abnormal stratification } \\
\text { - Papillary growth pattern } \\
\text { - Nuclear overlapping }\end{array}$ & $\begin{array}{l}\text { - Abnormal configuration: } \\
\text { acinar and palisade pattern } \\
\text { - Nuclear protrusion and } \\
\text { abnormal stratification }\end{array}$ \\
\hline Mucinproduction & $\begin{array}{l}\text { - Absence of mucous } \\
\text { background } \\
\text { - Mucous glands with polarity }\end{array}$ & $\begin{array}{l}\text { - Often mucous background } \\
\text { - Mucin-rich cytoplasm }\end{array}$ & $\begin{array}{l}\text { - Prominent mucous back- } \\
\text { ground } \\
\text { - Yellowish or polychromatic } \\
\text { mucin } \\
\text { - Mucin-rich cytoplasm and } \\
\text { compressed nuclei }\end{array}$ \\
\hline Nuclear findings & $\begin{array}{l}\text { - Small, round nuclei } \\
\text { - Isokaryosis }\end{array}$ & $\begin{array}{l}\text { - Oval, or round nuclei } \\
\text { - Anisokaryosis } \\
\text { - Intranuclear crease }\end{array}$ & $\begin{array}{l}\text { - Oval and elongated nuclei } \\
\text { - Admixture of anisokaryosis } \\
\text { and isokaryosis }\end{array}$ \\
\hline Chromatin pattern & $\begin{array}{l}\text { - Fine granular } \\
\text { - Homogeneous distribution }\end{array}$ & $\begin{array}{l}\text { - Coarse, hyperchromatic } \\
\text { - Heterogeneous distribution } \\
\text { - Nuclear dissolution }\end{array}$ & $\begin{array}{l}\text { - Fine or coarse chromatin } \\
\text { - Partial hyperchromasia }\end{array}$ \\
\hline Nucleoli & $\begin{array}{l}\text { - Unclear } \\
\text { - One, or absent }\end{array}$ & $\begin{array}{l}\text { - Prominent nucleoli } \\
\text { - Perinucleolar halo }\end{array}$ & $\begin{array}{l}\text { - Prominent, basophilic nu- } \\
\text { cleoli }\end{array}$ \\
\hline
\end{tabular}

(Compiled from references 2 and 3 and our observation)

Table 2 Histochemical findings in adenoma malignum and other columnar cells

\begin{tabular}{|c|c|c|c|c|c|c|}
\hline & \multicolumn{2}{|c|}{ Adenoma malignum } & \multicolumn{2}{|c|}{ Endocervical glands } & \multicolumn{2}{|c|}{ Gastric glands } \\
\hline & $\begin{array}{l}\text { Present } \\
\text { case } 1\end{array}$ & $\begin{array}{l}\text { Present } \\
\text { case } 2\end{array}$ & $\begin{array}{l}\text { Benign } \\
(\mathrm{n}=3)\end{array}$ & $\begin{array}{l}\text { Adenocarcinoma } \\
\qquad(\mathrm{n}=1)\end{array}$ & $\begin{array}{l}\text { Pyloric glands } \\
\qquad(\mathrm{n}=2)\end{array}$ & $\begin{array}{l}\text { Surface mucous cells } \\
\qquad(\mathrm{n}=2)\end{array}$ \\
\hline PAS & +++ & +++ & +++ & $+1-$ & ++ & +++ \\
\hline ALB & + & ++ & +++ & $+1-$ & + & - \\
\hline HID-ALB & $+1-$ & $+/-$ & +++ & $+1-$ & $+1-$ & - \\
\hline HIK-1083 & ++ & $+1-$ & - & - & + & - \\
\hline CEA & $-{ }^{*}$ & $-*$ & - & ++ & + & - \\
\hline p 53 & - & $-*$ & - & - & - & - \\
\hline
\end{tabular}

PAS : Periodic acid schiff, ALB : Alcian blue, HID-ALB : High iron diamine alcian blue, CEA : Carcinoembryonic antigen, ${ }^{*}$ : Weak, or few positive cells.

Classifications of positive cells $;+++:>80 \%,++: 80 \sim 60 \%,+: 60 \sim 30 \%,+/-: 30 \sim 10 \%,-:<10 \%$

強陽性，HIK 1083 抗体を用いた免疫染色でも陽性を 示した。これらの所見は前述のごとく，正常頸管腺粘 液とは明らかに異なる性状を示している，AMの細 胞形態学的診断においては，この heterogeneous な 粘液をいかに同定できるかが診断の重要なポイントと なろう。

次にその他の免疫染色および特殊染色所見について 述べる.CA 125 は症例 2 において反応の低下がみら

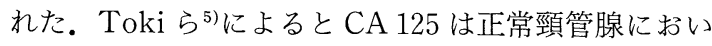
ては陽性だが，AM では発現が減弱すると述べてい る。また症例 2 では，リンパ節に転移する腫愓細胞の
みに p 53 が陽性であった。一般に p 53 は子宮頸部腺 上皮病変においては, 高悪性度群や病勢が著しく進行

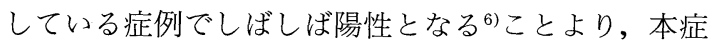
例も厳重な follow up が必要であると考える.

グリメリウス染色は症例 1 で陽性, 症例 2 で陰性で あった。好銀性顆粒は通常の子宮頸部腺癌に比して高 率に出現するとされておりり ${ }^{9)} \mathrm{AM}$ の特徵の 1 つと思 われた。

最後に今回われわれが子宮頸部擦過細胞診で $\mathrm{AM}$ を診断しえた理由の 1 つとして, 症例 1 では帯下の異 常な増加があるとの臨床側からの積極的なアピール， 
および臨床所見の詳細な報告があった。AMにおけ る腫瘍の肉眼的特徵として子宮頸部の腫大, 多囊胞形 成などが挙げられているが，これらの所見は時にコル ポ診でも見いだしうる。一方，組織診において AM は前述したように隆起性病変とは異なり異型の弱い腺 管の深部への浸潤を特徴としているため，生検だけで は正常の頸管腺や良性の過形成病変との鑑別が難し い.そのため頸部腫湯を認め，本腫瘍の存在が疑われ る場合には円錐切除術などによる深部の組織を含めた 組織の採取が必要となる。われわれの症例 1 では子宮 頸部擦過細胞診にて AM が示唆され，円錐切除術に よって早期に術前の診断ができた。症例 2 は症例 1 で の経験をもとに診断しえたといえよう。すなおち臨床 との密接な関わりを大切にした上で，詳細な観察から 腺異型を見落とさないことが重要であると思われる。

稿を終えるにあたりご協力を頂きました当院病理検查課暮生 吉彦技師，当院婦人科諸先生方に深謝いたします。

本論文の要旨は第 37 回日本臨床細胞学会秋期大会（1998 年 11月，仙台市）において発表した。

\footnotetext{
Abstract

Background : Cytomorphological diagnosis of adenoma malignum, a subtype of endocervical adenocarcinoma, is often difficult because the tumor cells closely resemble benign endocervical cells. We describe 2 cases of adenoma malignum diagnosed by endocervical scraping cytology.

Case: Two Japanese women aged 48 and 41 reported abnormal vaginal discharge. Adenoma malignum or its related tumors were strongly suspected from pelvic examinations, endocervical scraping cytology, and conization of the uterine cervix. In both, tumor cells from endocervical scraping were mucin-producing cells with minor cellular or nuclear atypia and a few cell clusters resembling endocervical adenocarcinoma. Histological examination of the resected uterus revealed atypical hyperplastic mucous glands invading to the profound layer. Most tumor cells were positive for HIK 1083 antibody and PAS staining. These cells demonstrated a decreased reaction to alcian blue and high iron diamine-alcian blue.
}

Conclusion: For the cytological diagnosis of adenoma malignum, we found the staining property of mucin and its histochemical findings are sufficient for differentiation. The correct diagnosis is made with the aids of relevant clinical information.

\section{文献}

1) Gusserow, A.L.S. Uber sarcom des uterus. Arch. Gynaekol. $1870 ； 240 \sim 251$.

2）芳賀厚子，平井康夫，荒井祐司，秋山太，南 敦子, 神谷真由美 - ほか。宮頸部悪性腺腫 (adenoma malignum）の臨床細胞学的検討. 日臨細胞誌 1995； $34: 1082 \sim 1088$.

3）荒井祐司，芳賀厚子，平井康夫，秋山 太，都竹正文， 山内一弘・ほか。宮頸部腺癌一Adenoma malignum の細胞像について一。 日臨細胞誌 $1999 ; 38 ： 1 〜 5$.

4) Ishii, K., Katsuyama, T., Ota, H., Watanabe, T., Matsuyama, I., Tsuchiya, S., et al. Cytologic and cytochemical features of adenoma malignum of the uterin cervix. Cancer (Cancer Cytopathology) $1999 ; 87: 245 \sim 253$

5) Toki, T., Shiozawa, T., Hosaka, N., Ishii, K., Nikaido, T., Fujii, S. Minimal deviation adenocarcinoma of the uterin cervix has abnormal expression of sex steroid receptors, CA 125, and gastric mucin. Int. J. Gynecol. Pathol. 1997; 16:111 116.

6) Toki, T., Ya-Li Zhai, Jong Sup Park, Fujii, S. Infrequent occurrence of high-risk human papillomavirus and of P 53 mutation in minimal deviation adenocarcinoma of the cervix. Int. J. Gynecol. Pathol. 1999 ; $18: 215 \sim 219$.

7) Ishii, K., Hosaka, N., Toki, T., Momose, M., Hidaka, E., Tsuchiya, S., et al. A new view of the so-called adenoma malignum of the uterin cervix. Virchows Arch $1998 ; 432: 315 \sim 322$.

8）石井恵子，岩原彩子，唐沢秀樹，渡辺達男，町田智恵， 上条朋美・棌か，異型のない黄色粘液細胞の出現が発見 のきっかけとなった子宮頸部悪性腺腫の 2 例. 日臨細胞 誌 $2000 ; 39: 99 \sim 103$.

9）森脇昭介，杉森 甫. 取り扱い規約に沿った腫瘍鑑別ア トラスー子宮頸部一。東京：文光堂, 1991；51～70. 


\section{写真説明}

Photo. 1 Case 1. Macroscopic findings revealed heavy mucous production and cystic changes of the uterine cervix (above).

Photo. 2 Case 2. Macroscopic findings of uterine cervix. Note the increased thickness of the uterine cervix (below).

Photo. 3 Case 1. Cytological findings of endocervical scraping. Acinic cell clusters (a : Papanicolaou stain, $\times 40)$ and atypical mucous-producing cells with compressed nuclei (b : Papanicolaou stain, $\times 40)$.

Photo. 4 Case 1. Imprint smear from the cut surface of the uterine cervix. Tumor cells have round or oval nuclei with a fine chromatin pattern and abundant cytoplasm. Occasional atypical columnar cells are observed. These cells are positive for HIK-1083 antibody (a, c : Papanicolaou stain, $\times 40$, b,d : HIK-1083, b $: \times 20, \mathrm{~d}: \times 40$ )

Photo. 5 Case 2. Cytological findings of endocervical scraping. Most tumor cells have yellowish mucin and compressed nuclei (a: Papanicolaou stain, $\times 100$ ). Imprint smear from the cut surface of the uterine cervix. Hyperplastic mucous cells (b : Papanicolaou stain, $\times 100)$.

Photo. 6 Case 1. Histopathological findings of the uterine cervix. Atypical hyperplastic mucous glands are observed (a : H \& E stain, $\times 10)$. These cells show positive staining for HIK-1083 antibody (b : HIK-1083, $\times 10)$. 

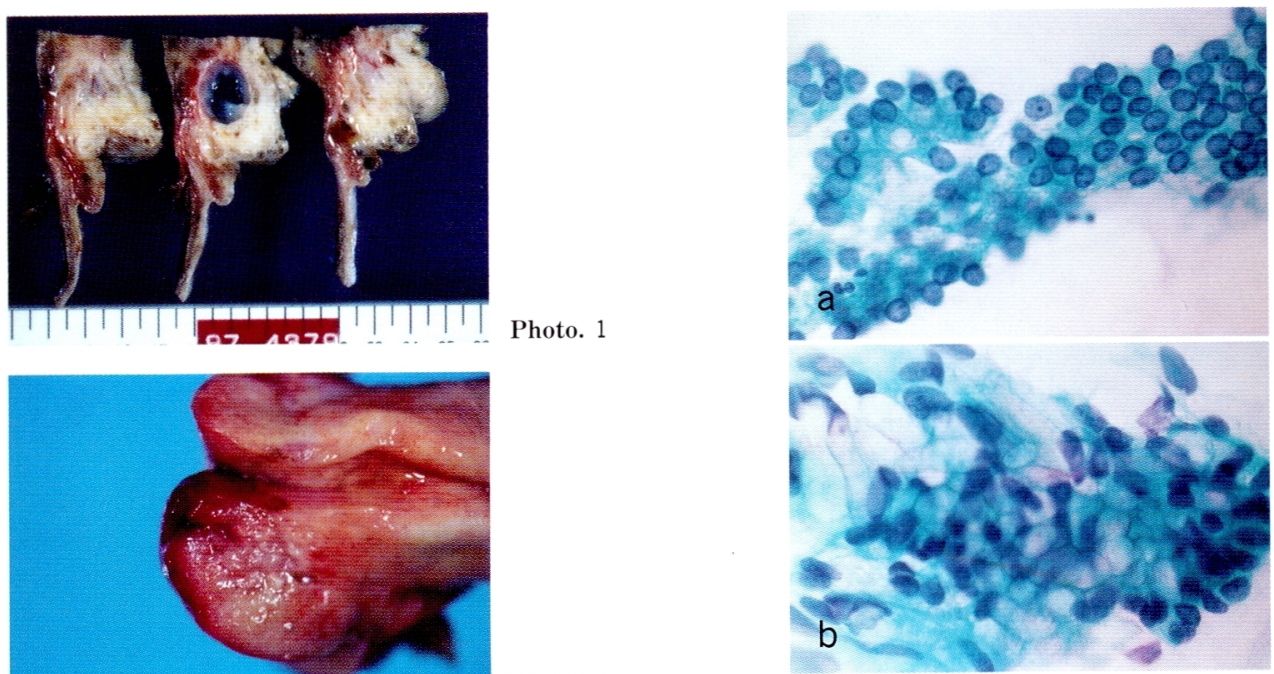

Photo. 2

Photo. 3
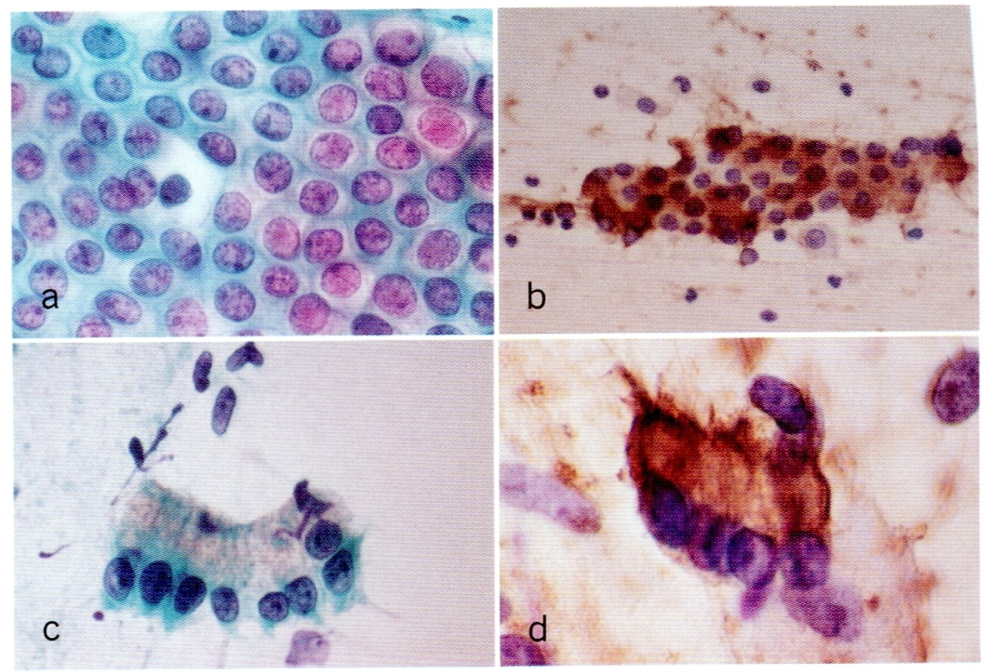

Photo. 4
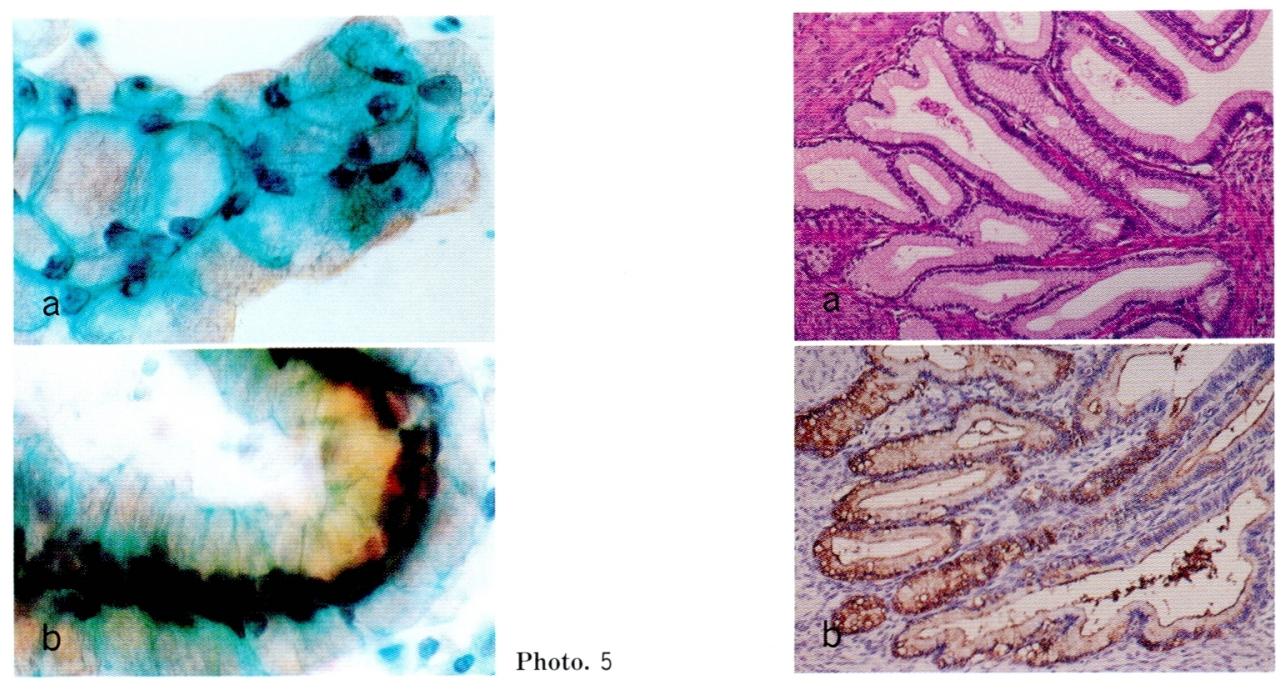

Photo. 5

Photo. 6 